\title{
Cointegration Analysis of Exchange Rate Volatility and Agricultural Exports in Turkey: an Ardl Approch
}

\author{
Turgut Orman ${ }^{1, a, *}$, Illkay Dellal ${ }^{2, b}$ \\ ${ }^{1}$ Department of Agricultural Economics, Field Crops Central Research Institute, 06170 Ankara, Turkey \\ ${ }^{2}$ Department of Agricultural Economics, Faculty of Agriculture, Ankara University, 06100 Ankara, Turkey
}

*Corresponding author

\begin{tabular}{l|l} 
A R T I C L E I N F O & A B S T R A C T \\
\hline Research Article & $\begin{array}{l}\text { This study aims to reveal the impact of exchange rate volatility on agricultural exports of Turkey } \\
\text { by using the Autoregressive Distributed Lag Model. While quarterly time series data covering } \\
\text { period of 2001: Q1 to 2018: Q4 were used to carry out analyses, Exponential Generalized } \\
\text { Autoregressive Conditional Heteroscedasticity (1.1) is used to acquire exchange rate volatility } \\
\text { series. The research findings showed that agricultural export is cointegrated with exchange rate } \\
\text { Accepted : 04/06/2021 } \\
\text { volatility, producer price index and real effective exchange rate. Furthermore, our findings indicate } \\
\text { that increases in real effective exchange rate have a statistically significant positive influence on the } \\
\text { export volume whereas exchange rate volatility has negative impact on it. }\end{array}$
\end{tabular}

Keywords:

Volatility

ARDL bounds testing

Producer price index

Agricultural exports

Real effective exchange rate

turgut.orman@tarimorman.gov.tr

(iD) https://orcid.org/0000-0002-4814-237X

|b@ilkay.dellal@ankara.edu.tr

iD https://orcid.org/0000-0002-8534-3031

\section{Introduction}

Agricultural exports have been playing a crucial role in national economies in terms of its contribution to the productivity of domestic production and income for the people involved in agriculture sector. Besides, it is a major source of foreign exchange that is necessary to finance imports and pave the way for development of other sectors particularly in developing countries (FAO, 1995). Turkey as a developing country, is not an exception to this fact. Agricultural export including food products has a share of nearly $10 \%$ in total exports of Turkey. Furthermore, Turkey is the leading exporter of many agricultural products such as nut, apricot, grapes, fig, quince and wheat flour in the world markets (Turkstat, 2020).

In recent years, agricultural exports and its relation with exchange rates have been an important area of policy discussions. Although the issue is on the stage for many transition economies throughout the world, Turkish case is more valuable to evaluate in terms of the effect of exchange rate and its volatility on the agricultural exports due to the unprecedented and intense movements in Turkish currency markets since the second quarter of the 2013.

There is a considerable interest in the literature to measure the effect of exchange rate and its volatility on the agricultural trade flows both for developed and developing countries. However, existing studies have not reached consensus on the significancy and direction of the effect. Some studies found that exchange rate volatility is an important determinant of Turkish agricultural export (Erdal et al., 2012, Yazici 2012), while others showed that exchange rate and its variability do not have significant impact on export (Buguk et al., 2003).

The results mainly vary acording to the selected period of time, variables used in the model and the countries studied. In this context, this study empirically investigates the impact of exchange rate volatility on the agricultural exports of Turkey employing Autoregressive Distributed 
Lag Model (ARDL) developed by Pesaran et al., 2001. While quarterly time series data covering period of 2001: Q1 to 2018: Q4 were used to carry out the analyses, Exponential Generalized Autoregressive Conditional Heteroscedasticity (EGARCH) (1.1) is employed to obtain exchange rate volatility series.

A Brief Overview of Agricultural Exports and Exchange Rate Markets in Turkey

There are three main classifications issued by the United Nations (UN) to record and measure trade data. Agricultural trade data is measured by selecting specific chapters and/or codes listed in those classifications (TURKSTAT, 2008). According to the International Standard Industrial Classification of All Economic Activities (ISIC) Rev. 3, agricultural exports are measured by summing chapters 01,02 and 05 -agriculture, hunting and forestry and fishing. Food industry products are not included in those chapters. Some selected chapters (01-24) from Harmonized System (HS) which is one of the detailed classifications used by World Trade Organization (WTO), Food and Agriculture Organization (FAO) and any national institutions to report agricultural export data, are generally used to define agricultural exports including food industry product (UNSD, 2008). Some selected chapters from Standard International Trade Classification (SITC) are also used to measure agricultural export data (UNSD, 2006).

Turkish agricultural exports were 6 billion USD in 2018 according to ISIC. On the other hand, it was 19.3 billion US Dollar (USD) when food industry products are included according to HS classification. Share of agricultural exports also varies according to classification selected. It is $3-4 \%$ according to ISIC and $10-11 \%$ according to HS/SITC (Table 1), (Turkstat,2020).

Main products exported in 2018 were nuts and fruits, citrus fruits or peel of melons $(12.8 \%)$, preparations of vegetables, fruits or other parts of plants $(6.3 \%)$ malt, starches, gluten, inulin and products of the millings industry (3.9\%), (Turkstat,2020).

Major export markets for Turkish agriculture in 2018 were Iraq (14.9\%), Germany (7.1\%), USA (7.7\%), Russian Federation (4.6\%) and Italy (3.6\%). It can be observed that there is a quite high concentration in agricultural export in terms of products and trade partners. The share of first three products in total agricultural exports was $23 \%$ and share of first five trade partners was 35\% in 2018 (Turkstat, 2020).

Turkey implemented a fixed exchange rate policy like many other developing countries until 1980. The policy has evolved from fixed exchange rate regime to flexibly managed exchange rate regime from that time onwards. Turkey has a floating exchange rate regime since 2001 and there are limited interventions by Central Bank of the Republic of Turkey (CBRT) to prevent excessive volatility in the currency markets (Aytac, 2016). Exchange rates, as it is one of the instrumental policy tools, have the ability to influence trade flows in open economies, especially in those which implement flexible regime. It affects the export, import, and prices of products worldwide.

As it can be seen from the Figure 1, there is an upward trend in Turkish currency markets since mid-2013. Turkish Lira is depreciating against US Dollar and Euro. This is calculated as one of the highest depreciations among the developing countries (Figure 1).

Real Effective Exchange Rate, which is obtained from CBRT database, is a basic indicator to measure the international competition power of Turkey against its trading partners. It is weighted average of the prices in Turkey relative to the prices of its main trade partners in international markets. A downward trend has been observed between 2001-2018 (Figure 2), (CBRT, 2020).

Exchange rate volatility is an important factor that has to be taken into account especially for developing countries such as Turkey. It has generally been assumed that volatility, meaning uncertainty can impose cost on the trade and may negatively affect the exports for risk-averse traders. However, there is no consensus on the relation between exports and volatility in the literature.

\section{Data and Methodology}

The empirical analysis is carried out using quarterly observations covering the period of 2001: Q1 - 2018: Q4. Deseasonalized real agricultural export (AGEXS) data obtained from TurkStat database is used for agricultural exports. The classification ISIC Rev.3 is selected. CPI based real effective exchange rate (REER) data, average quarterly value of the daily conditional heteroscedasticity for USD/TL exchange rate volatility (Kim, 2017) (REERV) which is obtained through EGARCH (1.1) and producer price index of agricultural products (AGPPI) are used in the model as explanatory variables. Log form of all series except exchange rate volatility are used in order to avoid excessive changes and having linear values (Ozer, 2013).

Engle (1982) and Bollerslev (1986) have stated that generalized autoregressive conditional heteroskedastic (GARCH) models are instrumental if we model the timevarying volatility of the time series. The conventional GARCH model allows the conditional variance to be dependent upon previous own lags. Exponential Generalized Autoregressive Conditional Heteroscedasticity (EGARCH) (1.1) introduced by Nelson (1991) is one of the techniques to determine the volatility in REER and to calculate REERV series. EGARCH models along with a conditional variance formulation are evaluated that they capture asymmetric response in the conditional variance successfully and had been proved superior to other asymmetric conditional variance in literature. As the non-negativity constraint in GARCH model can be violated by the estimated method, EGARCH is found more useful since variance will be positive although parameters are negative ( $\mathrm{Su}, 2010)$.

Findings of the EGARCH (1.1) model are shown in Table 2 and indicate that all parameters are statistically significant at $1 \%$ level of probability. Among all, $\alpha$ gives insight into the persistency of volatility and in case it is statistically significant, size of a shock has a significant impact on volatility. Meanwhile $\gamma$ gives insight into how the sign of a shock has an influence on the future volatility. If $\gamma$ is statistically significant and its coefficient is smaller than zero, it triggers a leverage effect where the volatility of a negative shock has greater effect than that of a positive shock (Table 2). 
Autoregressive Distributed Lag Model (ARDL), which is developed by Pesaran and Shin (1999) and Pesaran et al. (2001) has been performed to analyse impact of exchange rate and its volatility on agricultural exports. It relies on estimation of an Unrestricted Error Correction Model
(UECM) which is widely accepted as superior to other cointegration techniques. It can estimate short and long run coefficients simultaneously and is useful for small sample size. Besides, it can be used for variables composed of I (0) and I (1) levels (Srinivasan and Kalaivani, 2012).

ARDL model specification used in the paper is;

\section{- $\quad$ ARDL-UECM}

$\Delta$ lnagexs $_{t}=\alpha_{0}+\sum_{i=1}^{p_{i=1}} \beta_{1} \Delta$ Inreer $_{t-i}+\sum_{i=1}^{p_{i=1}} \beta_{2} \Delta$ lnreerv $_{t-I}+\sum_{i=1}^{p_{i}} \beta_{3} \Delta$ Inagppi $_{t-i}+\sum_{i=1}^{p_{i}} \beta_{4} \Delta$ lnagexs $_{t-i}+\gamma_{1}$ Inreer $_{t-1}+\gamma_{2}$ lnreerv $_{t-}$

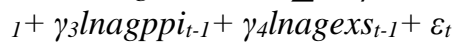

(Equation 1)

- Long-Run Relation

lnagexs $_{t}=a_{0}+\sum_{i=l}^{m_{i=l}} a_{1} \Delta$ lnreer $_{t-i}+\sum_{i=l}^{n} a_{2} \Delta$ lnreer $_{t-i}+\sum_{i=l}^{n} a_{3} \Delta$ lnagppi $_{t-i}+\sum_{i=l}^{q_{i=l}} a_{4} \Delta$ lnagexs $_{t-i}+\eta_{t} \quad$ (Equation 2)

- Short-Run Dynamics

$\Delta$ lnagexs $_{t}=b_{0}+\sum_{i=1}^{m_{i}} b_{1} \Delta$ lnreer $_{t-i}+\sum_{i=1}^{n} b_{2} \Delta$ lnreerv $_{t-i}+\sum_{i=1}^{y} b_{3} \Delta$ lnagppi $_{t-i}+\sum_{i=1}^{q_{i=1}} b_{3} \Delta \operatorname{lnagexs}_{t-i}+\prod_{1}$ ECM $_{t-1}+\psi_{t}$ (Equation 3)

Table 1. Turkish Agricultural Exports (Billion US Dollar)

\begin{tabular}{l|cccc}
\hline & HS $(0-24)$ & ISIC Rev3 (01, 02 and 05) & SITC (Selected Codes) & Total Exports \\
2014 & 18.0 & 6.4 & 18.7 & 157.6 \\
2015 & 16.8 & 6.1 & 17.4 & 143.8 \\
2016 & 16.2 & 5.8 & 16.9 & 142.5 \\
2017 & 16.9 & 5.7 & 17.3 & 157.0 \\
2018 & 19,2 & 6 & 18,1 & 168 \\
\hline
\end{tabular}

Source: TurkStat, Author's Calculations.

Table 2. EGARCH modelling of REER series

\begin{tabular}{l|cccc}
\hline \multicolumn{4}{c}{ Variance Equation } \\
\hline & Coefficient & Std. Error & Z-Statistic & Probability \\
$\omega$ & -2.816557 & 0.120350 & -23.40308 & 0.0000 \\
$\alpha$ & 0.261654 & 0.008810 & 29.69871 & 0.0000 \\
$\gamma$ & 0.062283 & 0.005165 & 12.05945 & 0.0000 \\
$\beta$ & 0.610182 & 0.017094 & 35.69482 & 0.0000 \\
\hline
\end{tabular}

6

4

2

0

200120022003200420052006200720082009201020112012201320142015201620172018

$\longrightarrow \mathrm{USD} / \mathrm{TL} \longrightarrow \mathrm{EURO} / \mathrm{TL}$

Figure 1. USD and EURO against Turkish Lira Source: CBRT.

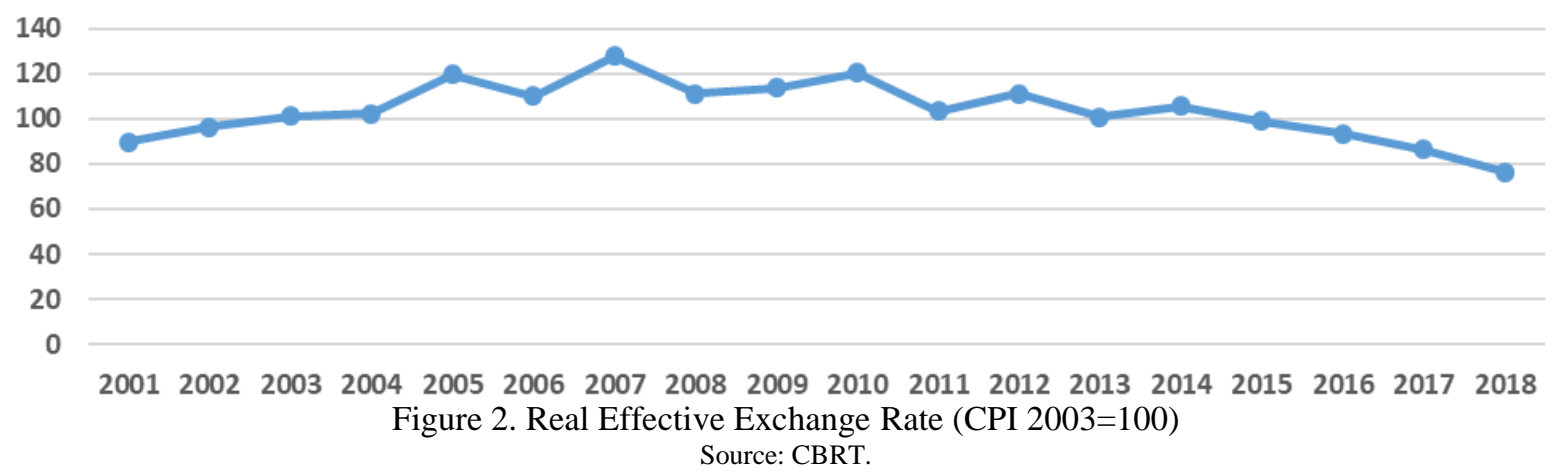




\section{Results and Discussion}

Augmented Dickey Fuller (ADF) unit root test results together with diagnostic and stability tests of ARDL are discussed in this section at first. Empirical findings derived from the aforementioned methodology to find the relation between real effective exchange rate, conditional heteroscedasticity for USD/TL exchange rate, producer price index and agricultural exports are described in the subsequent section.

\section{Preliminary Analyses}

We initially employ the standard ADF unit root test to find out at which level variables are stationary. Results are presented in the Table 3 .

\section{Diagnostic Tests and Stability of the ARDL Process}

Breusch-Godfrey Serial Correlation LM test and BreuschPagan-Godfrey Heteroscedasticity test were implemented in order to prove reliability of the ARDL model. Additionally, CUSUM and CUSUM of squares tests were implemented to examine its stability. As a result, null hypothesizes of both LM and heteroscedasticity tests were accepted, meaning that errors do not exhibit autocorrelation and they are homoscedastic (Table 4). Results of CUSUM and CUSUM of squares tests, which are presented in Figure 3 shows that there is no instability in the equation during the sample period.

\section{ARDL Cointegration Analyses}

Findings of ARDL Bounds test for cointegration are presented in Table 5. Bounds test result shows that the Fstatistic (5.94) exceeded the upper bound critical value at one percent significant level. Null hypothesis stating that there is no cointegration is rejected. It is confirmed that long-term equilibrium relationship is existed between Turkey's Agricultural export and USD/TL exchange rate volatility, agricultural producer price index and real effective exchange rate. Furthermore, cointegrated variables means that there is an adjustment process in the short run.

\section{ADRL Long-run Estimates}

As it is proved that independent and dependent variables are cointegrated, equation (2) which is selected according to Akaike Information Criterion (ARDL-
$3,0,0,3$ ) was estimated to obtain coefficients for long-run relationship (Table 6).

Results show that the impact of real effective exchange rate (lnREER) and producer price index (AGPPI) on agricultural exports of Turkey are positive and significant in the long run. Estimated coefficient of the exchange rate volatility (lnREERV) is negative but unable to secure statistical significance. More specifically, the results indicated that $\% 1$ increase in InREER and lnAGPPI led to a $0,63 \%$ and $0,74 \%$ increase in export volume respectively.

\section{ARDL Short-Run Estimates}

Equation (3) was estimated in order to obtain short-run dynamic coefficients of long-run relationship and its findings are presented in Table 6. The error correction model coefficient, which indicate speed of adjustment from short run to long run, is statistically significant and negative. This means that when Turkish agricultural export is deviating from long-run equilibrium level, $43 \%$ of that deviation is eliminated at each quarter of the year and around 7 months is needed for a full adjustment towards the long run equilibrium level.

Findings in the Table 7 show that the impact of reel effective exchange rate on agricultural exports of Turkey is positive and significant in the short run, meaning that higher reel effective exchange rate tends to increase agricultural exports in short run. Coefficients of exchange rate volatility and producer price index were negative but unable to secure statistical significance (Table 7).

Positive correlation between real effective exchange rate and export is prominent finding of our estimation whereas most studies in the literature suggest negative correlation (Kafle and Kennedy (2012)), (Cheung and Sengupta (2013)). On the other hand, an IMF Working Paper developed by Iossifov and Fei (2019) proved that export of Turkey increased during the period of appreciation of Turkish Lira. Much of this result is attributed to increasing total factor productivity of Turkey compared with its trading partners especially between 2000-2008. Inelastic demand of agricultural goods and Gross domestic product (GDP) of importing countries might be other factors that cause increasing export while REER is going up.
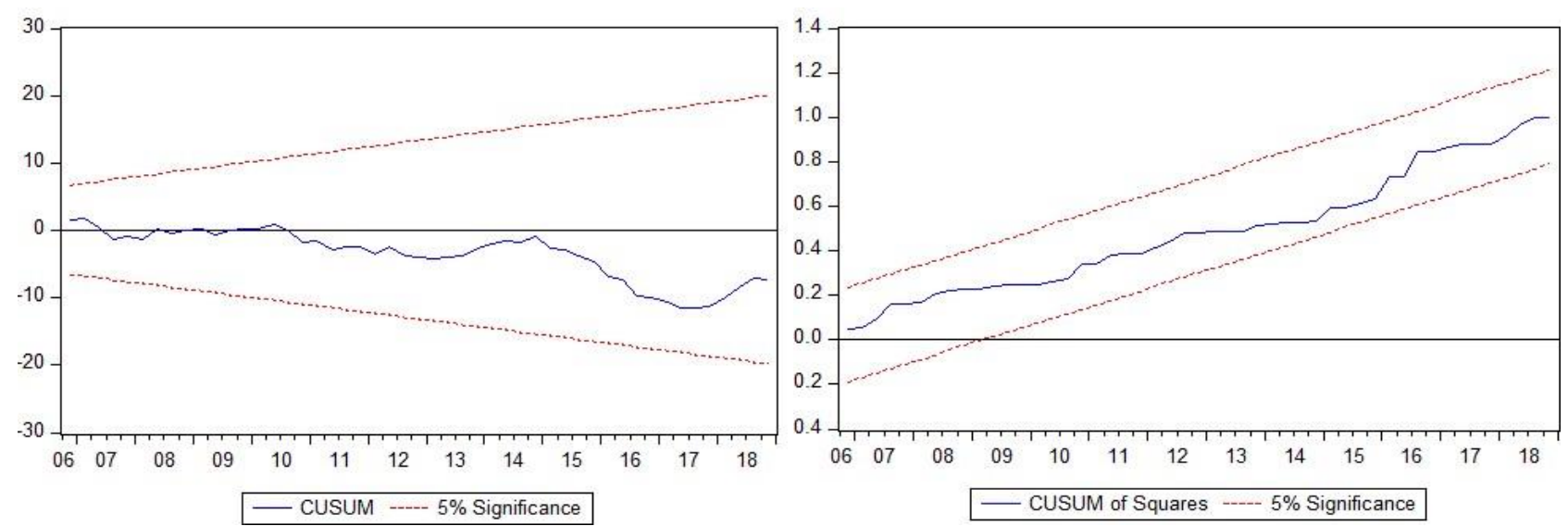

Figure 3. Cumulative Sum of Recursive Residuals 
Table 3. Results of Unit Root Test

\begin{tabular}{l|cccc}
\hline & \multicolumn{2}{|c}{ Level } & 1st difference & Decision \\
\cline { 2 - 5 } & Intercept & Intercept-Trend & Intercept & Intercept-Trend \\
\hline AGEXS & -1.889595 & -0.352469 & $-3.642520^{*}$ & $\mathrm{I}(1)$ \\
REER & -1.415140 & -1.618434 & $-8.612701^{*}$ & $\mathrm{I}(1)$ \\
REERV & $-8.660283^{*}$ & & & $\mathrm{I}(0)$ \\
AGPPI & - & & & $\mathrm{I}(0)$ \\
\hline
\end{tabular}

Note: $* * * * * *$ represents rejection of null hypothesis at $1,5,10 \%$ significance level. The variables are composed of $\mathrm{I}(0)$ and $\mathrm{I}(1)$.

Table 4. Diagnostic Tests

\begin{tabular}{l|clc}
\hline \multicolumn{5}{c}{ Breusch-Godfrey Serial Correlation LM Test } \\
\hline F-statistic & 2.014563 & Prob. F(2.54) & $0.1433^{*}$ \\
Obs*R-squared & 4.790864 & Prob. Chi-Square(2) & $0.0911^{*}$ \\
\hline \multicolumn{5}{l}{ F-statistic } & Heteroscedasticity Test: Breusch-Pagan-Godfrey & 0.5176 \\
Obs*R-squared & 0.937262 & Prob. F(12.56) & $0.4833^{*}$ \\
Scaled explained SS & 11.54031 & Prob. Chi-Square(12) & 0.6667 \\
\hline
\end{tabular}

Table 5. Bounds F-Test

\begin{tabular}{l|cc}
\hline \multicolumn{3}{c|}{ Computed F-Statistic: 5.94* $\mathrm{k}=4$} \\
\hline Significance & Lower Bound & Upper Bound \\
$10 \%$ & 2.45 & 3.52 \\
$5 \%$ & 2.86 & 4.01 \\
$2.5 \%$ & 3.25 & 4.49 \\
$1 \%$ & 3.74 & 5.06 \\
\hline
\end{tabular}

Notes: * indicates statistic exceeds upper bonds value at 1 percent significance level.

Table 6. Long-Run Coefficients of the ARDL $(3,0,0,3)$

\begin{tabular}{l|ccc}
\hline \multicolumn{1}{c}{ Regressor } & Coefficient & t-statistic & Prob.Value \\
\hline Constant & 3.725244 & 4.114341 & 0.0001 \\
lnREER & $0.638663^{*}$ & 2.657931 & 0.0102 \\
lnREERV & -0.001833 & -0.753474 & 0.4543 \\
$\ln$ AGPPI & $0.741602^{*}$ & 8.439292 & 0.0000 \\
\hline
\end{tabular}

Notes: $*(* *)$ represent significance at one and five percent level respectively.

Table 7. Error Correction Coefficients of the ARDL (3,0,0,3)

\begin{tabular}{|c|c|c|c|}
\hline \multicolumn{4}{|c|}{ Dependent Variable: $\Delta \ln$ AGEXS } \\
\hline Regressor & Coefficient & t-statistic & Prob.Value \\
\hline Constant & 3.725244 & 4.114341 & 0.0001 \\
\hline$\Delta \ln (\mathrm{AGEXS}(-1))$ & 0.253943 & 2.062005 & 0.0439 \\
\hline$\Delta \ln (\mathrm{AGEXS}(-2))$ & 0.100883 & 0.819242 & 0.4161 \\
\hline$\Delta \ln (\operatorname{AGEXS}(-3))$ & 0.209919 & 1.918714 & 0.0601 \\
\hline$\Delta \ln (\mathrm{REER})$ & $0.277981 * *$ & 2.332797 & 0.0233 \\
\hline$\Delta \ln (\mathrm{REERV})$ & -0.000798 & -0.725530 & 0.4711 \\
\hline$\Delta \ln (\ln A G P P I)$ & -0.060596 & -0.189089 & 0.8507 \\
\hline$\Delta \ln (\ln A G P P I(-1))$ & -0.187319 & -0.414788 & 0.6799 \\
\hline$\Delta \ln (\ln A G P P I(-2))$ & 0.110550 & 0.245234 & 0.8072 \\
\hline$\Delta \ln (\ln A G P P I(-3))$ & 0.460151 & 1.544850 & 0.1280 \\
\hline CointEq(-1) & -0.435256 & -5.005021 & 0.0000 \\
\hline
\end{tabular}

Notes: ${ }^{*}(*)$ represents significance at one and five per cent level respectively.

In contrast to relation between export and REER, our estimation is resulted in negative correlation between export and exchange rate volatility both in short and long run. While results of studies carried out by Thuy (2019) and Kafle and Kennedy (2015) are in agreement with our findings, Tunalığlu et al. (2013) and Erdal et al. (2012) found positive relationship between agricultural export and exchange rate volatility. Different results might be obtained depending on time period of analyses, sector and economic development level of examined country. In the light of our findings, it could be interpreted that having a sustainable and stable exchange rate may help to enhance real agricultural export. Additionally, it might be wise to improve capacity of Turkish exporting companies in terms of using hedging instruments which will help to cope with adverse currency movements. 


\section{Conclusion}

This study aims to reveal the impact of real effective exchange rate, USD/TL exchange rate volatility, producer price index of agricultural products on real agricultural exports of Turkey. For this purpose, ARDL methodology is implemented with quarterly data covering the period 2001: Q1 - 2018: Q4. Besides, volatility data has been obtained by using EGARCH (1.1) model.

The selected ARDL $(3,0,0,3)$ model, which is proved valid by diagnostic and stability tests, present that there is a long-run cointegration relationship among the variables.

The study results confirm that impact of real effective exchange rate (lnREER) on agricultural

exports of Turkey are positive and significant in both short and long run, implying that higher reel effective exchange rate tends to increase real exports. This may partly be explained by higher total factor productivity of Turkish agricultural sector compared with world average and importing countries.

On the other hand, estimated coefficient of the exchange rate volatility (lnREERV) was found to be negative and insignificant in both short and long run. This could be interpreted as adverse currency movements might be threat for Turkish export revenues in agriculture sector. Therefore, putting in place measures that will prevent unexpected currency movements may help to avoid risks associated with currency. In order to draw conclusions that generalize impact of exchange rate and its volatility on export, each country and each product need to be analyzed and it is necessary to take into account factors such as GDP, total factor productivity and demand elasticity of traded products. Such considerations are important next steps in the future analysis.

\section{Acknowledgments}

This article is produced from dissertation titled as The Effects of Exchange Rate Volatility on Turkish Foreign Agricultural Trade.

\section{References}

Aytaç Ö. 2016. Macroeconomic Developments and Exchange Rate Policy in Turkey, 1980-2001. Accounting and Finance Research, Vol. 5: No. 2.

Bollerslev T. 1986. Generalized Autoregressive Conditional Heteroscedasticity. Journal of Econometrics, 31: 307-27.

Bügük C, Işık M, Dellal İ, Allen A. 2003. The Impact of Exchange Rate Variability on Agriculture Exports of Developing Countries: The Case of Turkey. Journal of International Food-Agribusiness Marketing, 13: 83-105.

CBRT, 2020. https://www.tcmb.gov.tr: (Erişim tarihi: 20.12.2020)

Cheung YW, Sengupta R. 2013. Impact of exchange rate movements on exports: An analysis of Indian non-financial sector firms. Journal of International Money and Finance, Volume 39, December 2013, Pages 231-245.
Engle R. 1982. Autoregressive Conditional Heteroscedasticity with Estimates of the Variance of United Kingdom Inflation. Econometrica, 50(4): 987-1007.

Erdal G, Erdal H, Esengün K. 2012. The Effects of Exchange Rate Volatility on Trade: Evidence from Turkish Agricultural Trade. Applied Economics Letters, 19(3): 297-303.

FAO, 1995. The state of food and agriculture: Entering A New Era? Food and Agriculture Organization, Rome.

Kandilov IT. 2008. The effects of exchange rate volatility on agricultural trade. American Journal of Agricultural Economics, 90:1028-43.

Kafle KR, Kennedy PL. 2012. Exchange Rate Volatility and Bilateral Agricultural Trade Flows: The Case of the United States and OECD Countries. Southern Agricultural Economics Association Annual Meeting, selected paper.

Kim CB. 2017. Does exchange rate volatility affect Korea's seaborne import volume? The Assian Journal of Shipping and Logistics, 33(1): 043-050.

Ozer OO. 2013. Modeling the relationship between the beef producer price and the oil prices in Turkey. Journal of Food, Agriculture \& Environment, 11(3-4): 769-772.

Pesaran MH, Shin Y. 1999. An autoregressive distributed lag modelling approach to cointegration analysis. In: Strom, S., editor. Econometrics and Economic Theory in the 20th

Century. Cambridge: Cambridge University Press. p: 371-413.

Pesaran MH, Shin Y, Smith R. 2001. Bounds testing approaches to the analysis of level relationship. Journal of Applied Econometrics, 16(3): 289-326.

$\mathrm{Su}$ C. 2010. Application of EGARCH Model to Estimate Financial Volatility of Daily Returns: The empirical case of China. University of Göthenburg, Master Degree Project No.2010: 142.

Srinivasan P, Kalaivani M. 2012. Exchange Rate Volatility and Export Growth in India: An Empirical Investigation. Munich Personal RePEc Archive, Paper No. 43828.

Thuy VNT, Thuy DTT. 2019. The impact of exchange rate volatility on exports in Vietnam: A bounds testing approach. Journal of Risk and Financial Management, 12(1): 6.

Tunalioglu R, Ozer OO, Bayramoglu Z. 2013. Effect of volatility in real exchange rates and price changes on Turkey's olive oil export: an empirical study. The Journal of Actual Problems of Economics, (3): 448-458.

TURKSTAT, 2008. Dış Ticaret İstatistikleri ve Endeksleri, Sorularla Resmi İstatistikler Dizisi-2 (in Turkish). Turkish Statistical Institute, Ankara.

TURKSTAT, 2020. https://www.tuik.gov.tr/Home/Index: (Erişim tarihi: 20.12.2020)

UNSD, 2006. Standard International Trade Classification Revision 4, Department of Economic and Social Affairs Statistics Division. Statistical Papers Series M No. 34/Rev. 4, Rev.4, New York.

UNSD, 2008. International Standard Industrial Classification of All Economic Activities (ISIC) Revision 4, Department of Economic and Social Affairs Statistics Division, Statistical Papers. Series M No. 4, Rev.4, New York. 